\title{
THE ISSUE OF POLITICISATION OF MYSTICISM IN THE THEOLOGY OF DOROTHEE SÖLLE
}

K A T E Ř I N A M A J ER OVÁ

\begin{abstract}
The German Protestant theologian Dorothee Sölle, who came with the central ideas of relationship and reciprocity in the context of feminist liberation theology, accentuates what is known as the mysticism democratisation project. Within the framework of the project of the democratisation of mysticism, mystical sensitivity as a human constant that all people have without difference is thematised. In order to emphasise the equality and relationship between man and God as well as between man and others, she perceives mysticism as resistance: resistance against injustice and oppression in the world. According to Sölle, mysticism cannot be an elitist matter for a few people, nor should it be solely aimed at contemplation; it is necessarily related to the social, everyday reality of people, where the connection with God can be found. However, mysticism in terms of resistance against injustice and oppression is subject to objections because of the consequent politicisation and instrumentalisation of mysticism, which in turn may result in the secularisation of the mystical experience.
\end{abstract}

Key words

Mysticism; Resistance; Politics; Reciprocity; Responsibility

DOI: $10.14712 / 23363398.2020 .10$

$\mathrm{T}$ he German Protestant theologian Dorothee Sölle realised her theological considerations in the context of the feminist theology of liberation. In accordance with its perspective, the process of liberation emphasises the values of relationship and reciprocity in everyday 
life. ${ }^{1}$ Like the feminist theology of liberation, Sölle sees the necessity to declare the relationship and coherence of everything at the level of creation, which has its starting point in gender equality and must be realised within theory and practice. ${ }^{2}$ It is then the experience, especially the experience of women, their emotions, sexuality, and spirituality, together with their daily activities, which are at the centre of feminist liberation theology and Dorothee Sölle's theology.

Against the background of the disruption of the dichotomies between body and soul, nature ${ }^{3}$ and culture, Sölle also discusses the existential relationship between man and God, between man and nature, and between people since it is a relationship on the Me and $\mathrm{You}^{4}$ level, reflecting the essence of love - the gospel message of Jesus Christ. Jesus Christ, who is perceived as the liberator from patriarchal structures overcoming inequalities in the perspective of the feminist theology of liberation, is a reference to the reciprocity that underlies all relationships at the level of creation. ${ }^{5}$ Relationships within creation, everyday human experience, and the experience of oppression and liberation thus form the theological reflection of Dorothee Sölle. Every person is urged to follow the pattern of Jesus Christ and to continue the dynamic process of liberation, participating in that which happens here and now; this is a reference to hope in the context of everyday life. Like other theologies of liberation, the theological reflection of Sölle relates to the needs of people. In other words, she seeks God in the faces of the poor and marginalised in order to bring hope for liberation and

1 Dorothee Sölle, Gott denken: Ein führung in die Theologie (Stuttgart: Kreuz Verlag, 1992).

2 Rosemary Radford Ruether, 'The emergence of Christian feminist theology,' in The Cambridge Companion to Feminist Theology, ed. Susan Frank Parsons (Cambridge University press, 2004), 3-22.

3 The feminist theology of liberation discusses ecological overlaps associated with an ecofeminist perspective. From this perspective, they see a parallel between the devastation of nature and the historical oppression of women. See Karen J. Warren, Ecofeminist Philosophy: A Western Perspective on What It is and Why It matters (Rowman and Littlefield Publishers, 2000). The ecological perspective of theology emphasises the goodness of the creation that must be protected and cared for as it is an integral part of the love of neighbours. See Sallie McFague, 'The Ethic of God as Mother, Lover and Friend,' in Feminist Theology a Reader, ed. Ann Loades (Luisville: Westminster/John Knox Press, 1990), 255-274.

4 In the context of this relationship, the feminist theology of liberation refers to the thesis of Martin Buber. See Martin Buber, I and Thou (Mansfield Centre, CT: Martino Publishing, 2010).

5 Dorothee Sölle, Lieben und arbeiten: Eine Theologie der Schöpfung (Stuttgart: Kreuz-Verlag, 1985). 
to create a new life. ${ }^{6}$ Love for neighbours, interest in others, which neglects ignorance and blindness to the misery of neighbours, in other words, interest in the everyday reality of people, is also reflected in Dorothee Sölle's theology of mysticism, which primarily focuses on man, Earth, and the everyday.

\section{Mysticism in Everyday Life}

It is in the everydayness where Dorothee Sölle finds God. In the perspective of Sölle, God is not an isolated sovereign ${ }^{7}$, but through a panentheistic vision, a 'far away, but nearby's partner and friend, who is not dominated by the world, but who is in a dialogical relationship of mutual need..$^{9}$ According to Sölle, the relationship between man and God cannot be based on an unequal power relationship through blind obedience but on reciprocal love that stems from the liberated imagination. ${ }^{10}$

In Sölle's view, transcendence is a radical immanence; God is present in everyday life, not isolated from the needy, but He exists here and now as a response to the desire and call for him. ${ }^{11}$ To see God in the faces of the sufferers, in the everyday routine, according to Sölle, is a real mystical life, a living experience that reflects the unity and completeness of life, the interconnection of everything with everything. ${ }^{12}$ It means seeing God shattered in the poor and the rich, up and down, in the healthy and the sick, in the weak and powerful - that is a mystical life. ${ }^{13}$

6 Timothy Noble, 'Liberation Theology Today - Challenges and Changes,' in Mezinárodni symposium o teologii osvobození, ed. Michal Cáb, Roman Míčka, Marek Pelech (České Budějovice: Jihočeská univerzita, 2007), 22-36.

7 Sölle criticises the view of God as a powerful man-father, who would be a symbol of oppressive social structures that, as a result, view the relationship between man and God on the mighty-powerless plane. See Nancy Hawkins, 'Dorothee Soelle: Radical Christian and Mystic,' The Way: A Journal of Christian Spirituality, 44, no. 3 (2005): 89.

8 In this point, Sölle creates her ideas on the basis of the mystery of Marguerite Poréte and her vision of God as the far-near one. Dorothee Sölle, The Silent Cry: Mysticism and resistance (Minneapolis: Fortress press, 2001), 106.

9 Sölle, Mysticism and resistance, 106.

10 Dorothee Sölle, Phantasie und Gehorsam: Überlegungen zu einer künftigen christlichen Ethik (Stuttgart: Kreuz-Verlag, 1968).

11 Sölle, Gott denken, 249.

12 Dorothee Sölle, Mystik des Todes (Stuttgart: Kreuz Verlag, 2003).

13 Sölle, Mysticism and resistance, 283. 
The view of God as a partner in dialogue, not isolated from everyday life, is closely related to the positionality of Dorothee Sölle, shaped by the German and North American context of the 1960s and 1970s, anchored in liberation theology emphasising a 'starvation' for God as well as the desire to rediscover him everywhere in the world, in everyone's life. ${ }^{14}$ It is thus the feminist and liberation theology in which Sölle found the basis of her reflections which dealt with the questions of God's death and the atheistic belief in him. According to Sölle, God empowers man through Christ to be active and responsible for himself, the world, and others. ${ }^{15}$ Thus, through the events of World War II, Sölle came to the theology after the death of God, emphasising the need for a different speech and reflection on God in a secularised world. In other words, Sölle emphasises the immanent view of God, with the intention of targeting everyday life and transforming social reality. ${ }^{16}$

Everyday life as a mystical life, open to anyone, is not an exclusive affair of several people, but to a great extent leads the traditional unio mystica, the unification of the soul with God which is a consequence of the emphasis on a person and his or her everyday life with God. ${ }^{17}$ Sölle underlines that all people are mystics and each person possesses a mystical sensitivity which is a constant and which needs to be discovered and developed. ${ }^{18}$ So it can be said that Sölle refuses to perceive mysticism as the elitist, private affair of several individuals. For her, it is an integral life experience that any person can attain and participate in. Mystics are then ordinary people of different occupations for every person can achieve the rapprochement and the unification with God that happens in everyday life. Especially through the love of oneself, others, God and creation, this connection can take place. Against the background of the declaration of trust in a human being, in his or her good potential, which eliminates anthropological pessimism, ${ }^{19}$ Sölle emphasises a non-

14 Luise Schottroff, 'Come, Read with My Eyes,' Dorothee Soelle's Biblical hermeneutics of Liberation, in The Theology of Dorothee Soelle, ed. Sarah Pinnock (Trinity Press International, 2003), 45-47.

15 Dorothee Sölle, Christ the Representative: An Essay in Theology after the 'Death of God' (London: S.C.M.Press, 1967), 24-25.

16 Horst Georg Pöhlmann, Abriss der Dogmatik: Ein Kompendium (München: Gütersloher Verlagshaus, 2002), 136.

17 Peter Zimmerling, Evangelische Mystik (Göttingen: Vandenhoeck and Ruprecht, 2015), 193-194.

18 Sölle, Mysticism and resistance, 17-19.

19 For Sölle, humans are not powerless, but free beings made in the image of God. They are called to be co-creators with God in redeeming creation from sin. See Rosemary 
authoritative view of God and mysticism, emphasising the creation of everyone in the image of God and the creation of love: ${ }^{20}$ 'In a preliminary way, I can simply say that what I want to live, understand and make me known is the love for God ... One rarely hears that this process can be truly experienced only when such love, like every genuine love, is mutual. That humans love, protect, renew, and save God sounds to most people like megalomania or even madness. But the madness of this love is exactly what mystics live on. ${ }^{21}$

Mysticism, according to Sölle is the desire for God; thus it is a true fulfilment of the unity of life where a person loves God and God loves him or her reciprocally, through a relationship. Against the background of this relationship, Sölle accentuates the project of democratising mysticism, which opens up the space to experience God and make him accessible to everyone. In other words, it is a project of democratising mysticism that abstracts the limits and hierarchies of creation and perceives each person in the light of God's image. The aim is then to open the mystical experience to every person, without distinction. ${ }^{22}$ All people, as God's friends, can experience the presence and love of God, for God is common to all people, he does not divide but unites in his love. ${ }^{23}$ Thus, through the view of God as inseparable from creation, Sölle also rehabilitates that everydayness that incorporates the mystery of God and thus accentuates the trivialisation of life as the most powerful anti-systemic force. ${ }^{24}$

By rejecting the notion of trivial everydayness, along with moving away from seeing God as totally isolated from creation and human life, which entails breaking the boundary between man and God and confirming good human potential, Sölle comes to see mysticism in terms of resistance. Mysticism as a resistance, closely related to ethics, is a necessary prerequisite and consequence of the democratisation of mysticism, which opens up the space for every person not only to participate in the love of God but also to participate in creation through the defiance of injustice and ignorance. Through the existential combination

Radford Ruether, 'The Feminist Liberation Theology of Dorothee Soelle,' in The Theology of Dorothee Soelle, ed. Sarah Pinnock (Trinity Press International, 2003), 214. Dorothee Sölle, Lieben und arbeiten: Eine Theologie der Schöpfung (Stuttgart: Kreuz-Verlag, 1985).

21 Sölle, Mysticism and resistance, 1-2.

22 Ibid., 12.

23 Ibid., 18-19.

24 Ibid.,13. 
of mysticism, the mystical sensitivity of every human being with the transformation of inequalities at the level of creation, Sölle arrives at a certain vision of political mysticism and related criticism of the capitalist tendencies of society. ${ }^{25}$

\section{Political Mysticism as a Paradigm of the Theology of Dorothee Sölle}

The starting point of Dorothee Sölle in the context of mysticism is the fact that it is directed not only to itself but towards the whole, to the social reality. By comparing mysticism with resistance and highlighting that 'mysticism is a resistance', Sölle strictly defines everything which restricts and destroys the creation or dignity of each person. As Nancy Hawkins points out, 'mystical sensibility is an act of resistance for Dorothee Sölle. She cannot separate her understanding of mysticism from her social and political commitment. ${ }^{26}$ It is thus defiant conscious, active, inextricably linked to everyday oppression, which must be resisted..$^{27}$ The danger that Sölle sees in the individualistic tendencies of society, in technocracy, violence and terror, in ignorance and selfishness towards the needs of others is at the very heart of a vision of mysticism as a resistance that recognises the spreading danger of capitalism and sexism ${ }^{28}$ as well as the trivialisation of life. ${ }^{29}$

According to Zimmerling, 'her book is a "silent cry" against the screaming injustice in the world: both injustice in the Western states, which are the culprit of society itself, and against injustice committed by Western governments and economic cartels in the other two-thirds of the world'. ${ }^{30}$ The mysticism of Dorothee Sölle is basically a political

Ibid.,191-193.

26 Hawkins, 'Dorothee Soelle: Radical Christian and Mystic,' 93.

27 See Anne Llewellyn Barstow, 'Dorothee Soelle: Mystic/Activist,' in The Theology of Dorothee Soelle, ed. Sarah Pinnock (Trinity Press International, 2003), 189-201.

28 In the context of criticism of capitalism and sexism, Sölle also dissociates herself from the tendency to view sexuality, especially female sexuality, in terms of buying and selling, i.e. the tendency of society to regard anything as buyable. In the context of sexuality, it defines itself against the objectivisation of the female body and its use for capitalist and consumerist purposes, which imposes the idea of the female body as a means of achieving the goal of something that can be bought. See Dorothee Sölle, Lieben und arbeiten: Eine Theologie der Schöpfung (Stuttgart: Kreuz-Verlag, 1985), $156-160$.

29 Zimmerling, Evangelische Mystik, 192-193.

30 'Die Autorin erhebt in ihrem Buch "ein stilles Geschrei" gegen das schreiende Unrecht in der Welt: zum einen gegen das selbst verschuldete Unrecht in den westli- 
mysticism, in which she tries to highlight the goodness of Creation, which needs to be protected. Through rethinking the phases of mysticism and by following the mysticism of Master Eckhart, she emphasises the abandonment of and liberation from our selfish, egocentric self towards the transformation of self and society. ${ }^{31}$ In her political mysticism, Sölle is eager to show a connection with God in today's world, where individualising tendencies obscure service and compassion for others. The political basis and implication of mysticism can be attributed to Sölle's experience of its reflections dated to the political situation after World War II. The view of mysticism as a defiance with explicit political implications is reflected back in the theology of creation and in an attempt to break the strict boundary of the relationship between God and man. In particular, the aim is to enable and remind a person of his or her co-responsibility for the world, to encourage him or her to perform an activity instead of passively waiting for the help of God. ${ }^{32}$

Based on the mysticism of resistance, Sölle accentuates the mysticism of the open eyes - the mysticism of the poor, which is based on the theses of liberation theology in order to transform social inequalities. 'In the sense of theology that liberates, the soul that is united with God sees the world with God's eyes. That soul, like God, sees what otherwise is rendered invisible and irrelevant, ${ }^{35}$ she comments. In other words, we can say that the spiritual resistance contained in mysticism, in Sölle's perspective, is an expression of the strict rejection of those elements in the Church, in society, and in the political dimension, which devalue human beings, deny justice, and use force and human activity in an exploitative, oppressive manner. ${ }^{34}$

\section{Between Action and Contemplation}

From the point of view of mysticism as an active resistance, the efforts of Dorothee Sölle to emphasise engagement in society and responsibility for the world, which is, in her view, an essential part of

chen Staaten, zum andern gegen das Unrecht, das von den westlichen Regierungen und Wirtschaftskartellen in den Ländern der Zweidrittelwelt angerichtet wird.' See Zimmerling, Evangelische Mystik, 192-193.

31 Sölle, Mysticism and resistance, 59-60.

32 Ibid., 61-62.

33 Ibid., 283.

34 Hawkins, 'Dorothee Soelle: Radical Christian and Mystic,' 93. 
mysticism, are evident. It stands in contrast to the general notion of mysticism as Zimmerling observes: 'A common objection to mysticism is that it neglects engagement for society and for the fellow in favour of focusing on caring for one's own piety. ${ }^{35}$ However, in Dorothee Sölle's perspective, mysticism, viewed as resistance, limits the private focus to one's piety and refers to the necessity of action here and now, in a particular place, in other words, to conscious cooperation to transform social reality.

In the context of emphasising activity by Sölle, she reflects on the gospel story of two sisters, Mary and Martha (Lk 10:38-42), and explicitly follows the theses of Master Eckhart and Theresa of Avila by discussing via activa and contemplative principles which traditionally stand in contrast. Sölle consistently rejects the tendency to hierarchically order these two forces of life as well as the need to choose one. The reason is that, in the complex view of man, both forces are interrelated similarly to theory and practice. ${ }^{36}$ In other words, against the background of the story of Mary and Martha, Sölle declares the necessity of collaboration between activity and contemplation, where neither of them must be eliminated.

However, in the context of accentuating mysticism in resistance especially political mysticism, the thesis of Sölle faces criticism of the tendency to target the outside world instead of focusing on inwardness and contemplation. According to Zimmerling, 'more insidious is the danger that politics and defiance of faith and its mystical experience will engulf God. Out of the fear that internal engagement is not forgotten about engaging in the world, the inalienable right of faith to a contemplative dimension is neglected. ${ }^{57}$ With regard to the criticism of the politicisation, instrumentalisation, and functionalisation of mysticism, among others by Peter Zimmerling, ${ }^{38}$ the response can be found in Sölle's call to life 'without why'. Despite the fact that Sölle undeniably

35 'Ein häufig vorgebrachter Vorwurf gegenüber der Mystik lautet: Sie vernachlässige das Engagement für die Gesselschaft un den Nächsten auf Kosten der Konzentration auf die Pflege der eigenen Frömmigkeit.' See Zimmerling, Evangelische Mystik, 241.

7 'Virulenter ist die umgekehrte Gefahr, dass Politik und Widerstand den Glauben mitsamt der mystischen Gotteserfahrung aufsaugen.Vor lauter Angst,über der religiösen Erfahrung das Engagement in der Welt zu vergessen, bleibt das unverzichtbare Eigenrecht der kontemplativen Dimension des Galubens auf der Strecke.' See Zimmerling, Evangelische Mystik, 242-243.

38

Ibid., 241-243. 
associates mysticism with everyday reality and with human activity, contemplation - turning to ourselves and God through prayer within the context of mysticism - is also essential. In the context of prayer, where one, in Sölle's perspective, finds a friend and love in God and declares the transformation of a power relationship into a loving and close relationship, one also learns prayer and experience, the existence of sunder warumbe, without why ${ }^{39}$.

Following Master Eckhart's thoughts, Sölle considers life and prayer without why as a true hearing and answer to God's call. The principle of living without why is at the heart of mystical experience and refers to a spiritual practice that lives without intention, purpose, and power, and aims to live in the present moment. Life without why, contained in prayer itself, appreciates the beauty of creation and life itself, does not desire success or calculation of benefit; it is a principle that practically leads to resistance. ${ }^{40}$ As Hawkins writes, 'such a person is truly free to respond to God's grace as it influences their life'. ${ }^{41}$

It can therefore be said that, within the mysticism of Sölle, although she identifies it with resistance, she finds her origin in the purposeless prayer, in turning to ourselves, which is the result of the choice of life without why: 'If there is a verb for the life of mysticism, it is praying. This superfluous activity, this unproductive waste of time happens sunder warumbe, (without any why or wherefore). It is as free of ulterior motives as it is indispensable. Prayer is its own end and not a means to obtain a particular goal. The question "what did it achieve?" must fall silent in face of the reality of prayer. ${ }^{92}$

In the context of mysticism as a resistance, prayer and political responsibility have a crucial place; one cannot exist without the other. The interdependence of activity and passivity as well as the need for both of them thus replace the dependency model and simultaneously express freedom, which opens up the space to realise the coexistence, reciprocity, and participation of all in the gift of God. ${ }^{43}$ Therefore, in Sölle's perspective, through mystical unification the relationship to God does not change, but the relationship to the world does. Through the 'senses of God', man sees the world with humility and respect. Accord-

\footnotetext{
Sölle, Mysticism and resistance, 294-295.

40 Hawkins, 'Dorothee Soelle: Radical Christian and Mystic,' 88-89.

41 Ibid., 90.

${ }^{42}$ Sölle, Mysticism and resistance, 294.

43 Ibid., 294-295.
} 
ing to Nancy Hawkins this means 'to enter willingly into a relationship with God through prayer that will challenge, chase and disturb us' ${ }^{44}$

\section{Secularisation as the Cause and Effect of Dorothee Sölle's Mysticism?}

It is thus a certain 'displacement' of God which is criticised in the mysticism of resistance since it evokes a certain secularisation of mysticism along with a secular view of $\sin .{ }^{45}$ As Zimmerling writes, 'sin for Sölle apparently has no ontological quality. There is only a political, secular sin for her. ${ }^{46}$ This criticism therefore appears to be justified in view of the anchoring of the position of Sölle within the immanent, political eschatology, typical of liberation theologies. ${ }^{47}$ It is then the theological effort to reflect the everyday experience of oppression, suffering, and injustice, together with a call for engagement in the world, which can be discussed as a positive turning point in theology but with a certain risk of a one-sided conception of God. In order to include in the theological reflection the daily experience of oppression, which Sölle reflects largely globally and contextually indefinitely ${ }^{48}$, underestimates the unification of man and God and its overlap. In other words, in an attempt to empower a person and make him or her resist, Sölle does not consistently reflect on God's grace and His transcendence although her reflection takes place through prayer and a response to God's call. ${ }^{49}$

However, through the view of transcendence as a radical immanence that brings man closer to God, Sölle does not discuss the need not to separate but to distinguish God and as a result does not perceive God

\footnotetext{
Hawkins, 'Dorothee Soelle: Radical Christian and Mystic,' 89.

Zimmerling, Evangelische Mystik, 200.

46 'Sünde scheint für sie keine ontologische Qualität zu besitzen. Letztlich existiert nur politische, d.h. säkulare Sünde.' Zimmerling, Evangelische Mystik, 199.

47 Pöhlmann, Abriss der Dogmatik, 360-361.

48 Contextual impartiality, the ignoring of the context referred to, is one of the fundamental criticisms of the post-colonial feminist theology of liberation theology. Postcolonial feminist theology considers it necessary to discuss its position and location, which shapes the research interest, and, on the basis of this location, to define and specifically discuss the context that they thematise, especially to prevent false universalisation and generalisation. See Eleanor Tiplady Higgs, 'Postcolonial Feminist Theology,' in Gender: God, ed. Sian M. Hawthorne (Macmillan Reference USA, 2017), 79-93.It is then that the ignorance of the context, the everyday reality of the poor, of which Sölle reports, is criticised because of the absence of her personal experience in this context. See Zimmerling, Evangelische Mystik, 190.

Zimmerling, Evangelische Mystik, 197-198.
} 
as static and dynamic, as among others the Old and New Testament reminds man. ${ }^{50}$ By violating God's omnipotence with the intention of inducing man to actively participate and transform social reality, Sölle does not accentuate the depth and, to a large extent, the 'mysterium unio mystica', the union of the soul with God. In the context of Sölle's tendency to reduce mysticism to resistance in particular, Peter Zimmerling's criticism appears to recall that, although a mystic committed to the world and social reality is a substantial counterbalance to earlier tendencies, it cannot remain a resistance only. It should also include what remains largely near and far, known and unknown. ${ }^{51}$

\section{Conclusion}

In her approach to mysticism, Dorothee Sölle combines the visions of the feminist theology of liberation, in particular the declaration of values of relationship and reciprocity, together with her own location, anchored and influenced by the socio-political discourse of the 1960s and 1970s. In mysticism, Sölle sees resistance connected with political awareness, social, and environmental responsibility, to which prayer and a life of the so-called sunder warumbe - without why - necessarily lead. Thus, in the context of mysticism, Sölle proclaims action along with contemplation, which is a prerequisite of mysticism, i.e. one needs the other. Thus, mysticism as a resistance, of which ethics is an essential part, is reached through a project of democratisation of mysticism, which opens up the space for every man because God is common and belongs to everyone.

Through the perception of mysticism as a non-authoritarian, non-elitist relationship to God which is anchored in the theology of creation and in the disruption of the strict separation between God and man, each person is regarded as a mystic as her or she possesses an essential mystical sensitivity that enables everyone to unite with God. The view of mysticism as a resistance, in which Sölle reduces to some extent God's omnipotence, is subject of multilateral criticism along with her theologically inadequate reflection of unio mystica, for example by Peter Zimmerling.

50 Pöhlmann, Abriss der Dogmatik, 152-153.

51 Zimmerling, Evangelische Mystik, 200-201. 
It is through the reduction of God's omnipotence and a focus on God's immanence in particular that Sölle outlines a certain trivialisation, a simplification of transcendence, together, as Zimmerling noted, with a certain trivialisation of unio mystica. It is possible to say, that Sölle declares the necessity of unio mystica in the relationship of man to God, man to others and to himself. That means, in connection with God, one can achieve transformation of oneself in the form of self-liberation as well as transformation of everyday reality, to which the mysticism of resistance relates. Mysticism as a resistance can thus be perceived as a call for social responsibility and a declaration of positive human potential that will enable one to accentuate relationship and reciprocity within creation more consistently.

Although the mysticism of Dorothee Sölle can be seen as an attempt to emphasise social, political, and environmental awareness, it also entails the loss of the inwardness and indescribability of unio mystica together with the author's rejection of extreme individualism. It is then unio mystica, a connection with God, which refers to the mystery of transcendence. Although Sölle calls for a view of transcendence in conjunction with immanence in the context of the theology of creation, in the context of mysticism, this tension between transcendence and immanence borne out by the life and actions of Jesus Christ is inconsistently obscureed. Thus, the idea of the mystic of resistance can be seen as an adequate effort to bring man closer to God in response to the secularised, anthropocentric tendencies of society. However, in the question of politicising mysticism and focusing on immanence, seems to be a fundamental reminder of Pöhlman's remark - the world is still created by God, who empowers a person for social engagement and activity. ${ }^{52}$

Faculty of Theology, University of South Bohemia in České Budéjovice Knéžská 8

37001 České Budéjovice Czech Republic E-mail:majerk00@tf.jcu.cz

52 Pöhlmann, Abriss der Dogmatik, 153. 